\title{
Бунт гревтунгов во Фригии в 399-400 гг.: пример неудачной адаптации варваров в Восточной Римской империи
}

\author{
А.Д. Назаров \\ Уральский федеральный университет, \\ Россия, 620002, г. Екатеринбург, ул. Мира, 19 \\ E-mail: andrey.nazarov451@gmail.com
}

\begin{abstract}
Аннотация. В статье анализируются причины и характер восстания готов-гревтунгов во Фригии в 399-400 гг. Регулярные части из этих варваров были сформированы в 395-396 г. и отправлены на защиту Осроены от гуннов-хионитов. После окончания военных действий они были переведены обратно во Фригию, в которой проживали с 386 г. Следом гревтунги подняли мятеж, поводом к чему стал отказ препозита священной опочивальни Евтропия вознаградить варваров за боевые успехи. Это решение было воспринято готами как игнорирование заслуг, которое они предпочли компенсировать за счет грабежа городов и деревень в диоцезе Азия. Мигрировавшие в империю в 386 г. гревтунги были объединением воинов, идентичность которого основывалась на совместном участии в военных походах. Соответственно, многие проблемы, возникавшие перед ними, они пытались решать, используя грубую силу. Отдельного внимания заслуживает мотивация командира отряда гревтунгов Трибигильда. Несмотря на то, что этот военачальник находился в восточноримской армии на постоянной службе, он продолжал восприниматься рядовыми готами как вождь, который должен обеспечить справедливое распределение добычи. Трибигильд же рассматривал бунт против императора как способ сохранить авторитет в глазах своих сородичей и соратников.
\end{abstract}

Ключевые слова: Восточная Римская империя, Византия, византийская армия, готы, гревтунги, антропология насилия.

Благодарности: исследование проведено при поддержке РНФ, проект № 20-18-00240 «Этика войны в странах православной культуры: осмысление индивидуального опыта и реконструкция нормативной модели поведения».

Для цитирования: Назаров А.Д. 2020. Бунт гревтунгов во Фригии в 399-400 гг.: пример неудачной адаптации варваров в Восточной Римской империи. Via in tempore. История. Политология, 47 (4): 704-713. DOI: 10.18413/2687-0967-2020-47-4-704-713.

\section{The mutiny of Greuthungs in Phrygia, 399-400: an example of unsuccessful adaptation of barbarians in the East Roman Empire}

\author{
Andrey D. Nazarov \\ Ural Federal University, \\ 19 Mira St., Ekaterinburg, 620002, Russia \\ E-mail: andrey.nazarov451@gmail.com
}

\begin{abstract}
The article analyzes a character and reasons of the mutiny of Goths-Greuthungs in Phrygia in the years 399-400. Regular units of these barbarians were formed in 395-396 and sent to protect Osroene from the Huns-Chionites. After the end of the war, they were transferred back to Phrygia where Greuthungs had lived since 386. Afterwards, they revolted because of reject of the praepositus sacri cubiculi Eutropius to reward for the military success. Greuthungs perceived this decision as inobservance to their merits and chose to compensate for this by plundering towns and villages in the diocese Asia. Greuthungs which migrated to the Empire in 386 were a war band. Its identity based on common participation in warfare.
\end{abstract}


Accordingly, they tried to decide problems that arose before them using brute force. Special attention should be paid to the motivation of Tribigildus who was the commander of Greuthungs. Despite the fact that he served in the East Roman army on the regular basis, Tribigildus continued to be perceived by ordinary Goths as a leader who should ensure equitable distribution of booty. This commander considered mutiny against the East Roman emperor as a way to maintain authority among his relatives and associates.

Keywords: East Roman Empire, Byzantium, Byzantine army, Goths, Greuthungs, anthropology of violence.

Acknowledgments: the study was carried out with the support of the Russian Science Foundation, project No. 20-18-00240 «Ethics of war in the countries of Orthodox culture: comprehension of individual experience and reconstruction of the normative model of behavior».

For citation: Nazarov A.D. 2020. The mutiny of Greuthungs in Phrygia, 399-400: an example of unsuccessful adaptation of barbarians in the East Roman Empire. Via in tempore. History and political science, 47 (4): 704-713 (in Russian). DOI: 10.18413/2687-0967-2020-47-4-704-713.

Варварские миграции конца IV-V в. поставили Римскую империю перед проблемой размещения переселенцев на своей территории, устранения или по меньшей мере минимизации угроз, исходивших от иммигрантов. Восточная Римская империя сумела сохранить свою государственность, что свидетельствует об эффективности ее политики интеграции варваров в ранневизантийское общество. Однако также известны примеры, когда она терпела неудачи в такого рода мероприятиях. К их числу относятся действия препозита священной опочивальни (praepositus sacri cubiculi) Евтропия в отношении гревтунгов, размещенных во Фригии. Следствием неудачных решений этого приближенного императора Аркадия стал бунт, поднятый германцами в 399 г.

Сведения о самом мятеже сохранились в поэме Клавдия Клавдиана «Против Евтропия», исторических сочинениях Филосторгия, Сократа Схоластика, Созомена, Евнапия Сардийского, Зосима. Также в этих источниках содержится информация о положении гревтунгов в обществе империи и о сформированных из их числа отрядах в составе восточноримской армии. Кроме того, необходимо обратиться к агиографическому сочинению, в котором повествуется о мученичествах Гурия, Самона и Авива, а также о чуде, приписанном упомянутым святым. В этом нарративном памятнике, созданном Феофилом Эдессянином, зафиксированы уникальные сведения об участии гревтунгов в боевых действиях против гуннов-хионитов в Северной Месопотамии в конце IV в. ${ }^{20}$

Следует отметить, что событиям 399-400 гг., когда против императора Аркадия один за другим восстали восточноримские военачальники готского происхождения Трибигильд и Гайна, посвящена обширная историография. Однако «Деяния эдесских исповедников Гурия, Самона и Авива» исследователи, обращавшиеся к этим сюжетам, прежде не привлекали [Вольфрам, 2003, с. 213-217; Albert, 1984; Liebeschuetz, 1990, p. 100-125; Heather, 1991, p. 207-208; Cameron, Long, 1993]. Кроме того, необходимо уточнить, какие причины вынудили гревтунгов поднять мятеж, учитывая характерные для древних германцев представления о власти. Проблема взаимоотношений этих иммигрантов с мирным населением восточных провинций империи также заслуживает более пристального внимания.

Значительная часть «Деяний эдесских исповедников Гурия, Самона и Авива» посвящена непосредственно сирийским мученикам, пострадавшим за христианскую веру при Диоклетиане (285-305) и Лицинии (308-324). Кроме того, как отмечалось ранее, в этом литературном памятнике идет речь о чуде Гурия, Самона и Авива. Представляется

${ }^{20}$ В ходе исследования были привлечены различные версии «Деяний эдесских исповедников Гурия, Самона и Авива», имеющие между собой незначительные расхождения: сирийский первоисточник (с оригинальным текстом и английским переводом Ф. Бёркитта), а также более поздние греческий и латинский переводы [Dobschütz, 1911; Burkitt, 1913; Chiesa, 1991]. См. также статью Е.Н. Мещерской о Гурии, Самоне и Авиве в «Православной энциклопедии» [Мещерская, 2006]. 
необходимым привести краткий пересказ этого сюжета. Итак, в 395-396 г. в Осроену вторглись гунны, угрожая Эдессе (совр. Урфа), вследствие чего на защиту города была отправлена армия, в которой находился отряд готов. Некий германец во время постоя в Эдессе потребовал у богатой вдовы Софии отдать ему в жены дочь Евфимию. После долгих уговоров она согласилась, но заставила варвара поклясться в верности Евфимии в церкви у могил Гурия, Самона и Авива. Гот, однако, умолчал о том, что уже состоял в браке. Между тем гунны отступили из Осроены, после чего варвары покинули Эдессу.

Вернувшись к сородичам, германец ввел в дом Евфимию как простую служанку, скрыв от семьи свою неверность. Впоследствии уроженка Эдессы родила от него сына, который был отравлен женой гота, догадавшейся об измене мужа. Вслед за этим Евфимия сама отравила ту женщину. За убийство сирийка была приговорена к смерти, однако ночь перед казнью она должна была провести в гробнице с покойной супругой гота. Благодаря молитвам к ней на помощь явились Гурий, Самон и Авив, которые перенесли девушку в Эдессу. Когда на Востоке началась новая война, гот вернулся в Осроену и при встрече с Софией и Евфимией сознался в своих злодеяниях. В конечном итоге варвар был передан византийским властям и казнен.

Н.В. Пигулевская отметила, что сведения о мученичествах Гурия, Самона и Авива имеют под собой историческую почву [Пигулевская, 2017, с. 138-139]. Значительная часть информации «Деяний эдесских исповедников...» о событиях конца IV столетия также основывается на реальных событиях. В частности, об участии «гетов» в боевых действиях против гуннов, опустошивших Закавказье, Каппадокию и Северную Месопотамию в 390-х гг., сообщал Клавдиан (Claud. In Ruf. I. 242-251). Согласно Филосторгию, в то время, когда Фракию разорили подунавские гунны, другие гунны, жившие к востоку от последних, ворвались через Каспийские ворота в Армению, а уже оттуда двинулись в Сирию (Philost. XI. 8).

О вторжении «кионайе» (حتحس) в Осроену в 395-396 г. упоминал сирийский писатель Псевдо-Иешу Стилит (Иешу, 9). Вероятно, речь шла о хионитах, господствовавшем в IV столетии в Трансоксиане и Бактрии союзе кочевых племен. В греческой версии «Деяний эдесских исповедников...» римляне противостояли «эфталитам, соседствующим с персами и живущим там, где восходит Солнце» (oi 'Е

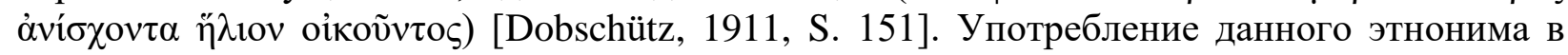
повествовании о событиях конца IV в. является анахронизмом, поскольку держава эфталитов возникла в Центральной Азии только во 2-й пол. V в. [Golden, 1992, p. 79-81; Felix, 1992; Bivar, 2004]. Так или иначе, можно утверждать, что восточные провинции империи были атакованы не подунавскими гуннами, а хионитами. Последние же в IV в., вероятно, распространили свою власть на кочевников Северного Кавказа [ср.: Гадло, 1979, с. 18].

Н.А. Ганина полагает, что сообщение о захоронении Евфимии рядом с госпожой связано с распространившимися среди сирийцев слухами о подобного рода ритуальных практиках готов. Действительно, известен погребальный обряд восточных германцев, в соответствии с которым они хоронили слуг вместе с господином. Российская исследовательница к тому же высказала мнение, что сам образ варвара в «Деяниях эдесских исповедников...» отражал неприязнь к готам, которую испытывало большинство жителей Восточной Римской империи [Ганина, 2001, с. 135-136].

В данном агиографическом произведении упоминается, что безымянный гот, женившись на Евфимии, вернулся к своей семье, утаив измену от супруги. Достоверность такого сообщения весьма сомнительна. Представляется маловероятным, что зажиточная сирийка могла выдать свою дочь замуж не просто за чужака, но и к тому же за варвара, который едва ли мог уверенно изъясняться на греческом языке, не говоря уже о сирийском. К тому же гот не обладал ни значительными богатствами, ни даже сколь-нибудь весомым положением в римской военной иерархии. Таким образом, сюжет о женитьбе гота на уроженке Эдессы является плодом литературного вымысла, прологом к назидательной истории о последующем чудесном спасении сирийки и наказании варвара за вероломство. 
Вымыслом также является сообщение о возвращении гота в Эдессу в связи с новой войной. После отражения набега хионитов в 395-396 г. крупные военные силы вновь были сосредоточены в Месопотамии только в 420-422 гг., когда Византия вела масштабные боевые действия против Ирана. Однако, как будет рассмотрено позднее, большая часть готов-гревтунгов была перебита в ходе подавления поднятого ими в 399 г. мятежа, а также во время разгрома восстания Гайны, к которому они примкнули позднее. Феофил Эдессянин упомянул, что при возвращении гота в Эдессу этому городу угрожали персы и гунны [Dobschütz, 1911, S. 186; Burkitt, 1913, p. 146; Chiesa, 1991, p. 251]. Вероятно, в данном случае сообщалось о нашествии, которому подверглась Осроена в 502 г. В начале VI столетия в византийскую часть Месопотамии вторглась персидская армия, которой командовал сам шаханшах Кавад I. В ней находились и эфталиты, с которыми иранский правитель тесно сотрудничал (Рroc. BP. I. 7. 6; 8. 13).

А. Джоунз рассмотрел историю о Евфимии и готе в контексте проблемы взаимоотношений между мирными жителями и солдатами, размещавшимися у них на постое. По его словам, различные обиды и неудобства, доставляемые воинами гражданскому населению, были в позднеантичный период обычным явлением. При этом он отметил, что упомянутый в агиографическом сочинении гот вовсе не обязательно был варваром. Как полагал А. Джоунз, в данном случае речь шла о собирательном образе солдата в восприятии сирийцев [Jones, 1964, p. 632 and n. 54]. Д. Ли согласился с мнением А. Джоунза. Он добавил, что подобные случаи фактического многобрачия были широко распространены среди воинов, которые часто покидали своих законных жен по долгу службы, хотя, конечно, такие союзы были незаконны [Lee, 2007, p. 150-151].

Вместе с тем заслуживают упоминания сведения Псевдо-Иешу Стилита о размещении готов-федератов в Эдессе в 505-506 г. Сирийский писатель в гиперболизированной манере описал неприятности, которые доставили варвары горожанам (Иешу, 93-96). Не исключено, что осуждение готов за бесчинства, которые они учинили в годы правления Анастасия I (491-518), в «Деяниях эдесских исповедников...» было перенесено на германца, находившегося на службе Аркадия (395-408). Это позволяет предположить, что та часть агиографического сочинения, которая посвящена Евфимии и готу, была создана не ранее начала VI столетия. Аргументом в пользу такой гипотезы служит и присутствие этнонима «эфталиты», с которыми Византия впервые столкнулась во время войны против Персии 502-506 гг., в греческой версии этого литературного памятника. Феофил Эдессянин видел в готах исключительно источник проблем, чужаков, постоянно провоцирующих конфликты. Как следствие, в сюжете, посвященном событиям конца IV в., варвару так же была дана негативная характеристика. Таким образом, при создании «Деяний эдесских исповедников...» произошла контаминация двух разных сюжетов из истории позднеантичной Эдессы, которые разделяет почти целое столетие. Объединяет же их то, что они связаны с участием отрядов готов в кампаниях империи в Месопотамии.

Х. Вольфрам в этой связи отметил: «Если готы чувствовали, что римляне, среди которых они жили, ущемляли их права, то они брали дело в свои руки и поступали в соответствии со своими обычаями и привычками» [Вольфрам, 2003, с. 193 и прим. 103]. Идентичность многих варварских объединений периода Великого переселения народов основывалась на совместном участии в военных походах. Как подчеркивает Г. Берндт, «для них физическое насилие определило главный, даже фундаментальный фактор их существования». Более всего в такой среде ценились навыки владения оружием, с помощью которого бойцы могли не только защититься от врага, но и принудить побежденного к исполнению собственной воли [Berndt, 2017, p. 18-19]. Размещенные в Эдессе готы воспринимали ее обитателей не как подданных императора, которыми были и сами варвары, но как объект эксплуатации, конфликт с которым можно разрешить с помощью применения грубой силы [см. также: Козлов, 1973, с. 114-115]. 
Гот, взявший Евфимию в жены, по всей вероятности, числился в составе регулярного подразделения, состоявшего из гревтунгов. В источниках встречаются упоминания об этих германцах, живших близ Наколеи (совр. Сейитгази) во Фригии Невредимой (Phrygia Salutaris), провинции в составе диоцеза Азия (Philost. XI. 8; Zos. IV. 13. 2). В историографии депортация этих варваров на Восток связывается с сообщением ранневизантийского историка Зосима о разгроме гревтунгов под предводительством Одотея во Фракии в 386 г. (Zos. IV. 38-39. Cf.: Claud. In Eutrop. II. 582). Исследователями признается, что уцелевшие в том бою германцы были переселены во Фригию [Вольфрам, 2003, с. 214; Seeck, 1913, S. 306-307; Albert, 1984, S. 89-90; Cameron, Long, 1993, p. 112-113]. Согласно утверждению Ал. Кэмерона и Ж. Лонг, эти варвары имели статус dediticii («сдавшиеся») и были поселены в Малой Азии как колоны [Cameron, Long, 1993, p. 113].

Представляется вероятным, что именно эти гревтунги были задействованы в обороне Эдессы от хионитов. Перед кампанией против кочевников, как считали Ал. Кэмерон и Ж. Лонг, из их числа были сформированы регулярные подразделения [Cameron, Long,

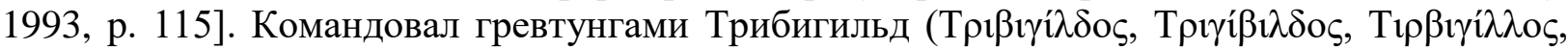
Tarbigilus), который был назван в сочинении Сократа Схоластика трибуном ( $\chi \lambda i \alpha \rho \chi о \varsigma)$ (Socr. VI. 6) [Martindale, 1980, p. 1125-1126]. Однако, по словам Филосторгия, этот германец состоял в восточноримской армии, занимая должность комита (ко́ үүґо)) (Philost. XI. 8). Зосим же писал, что он возглавлял «алы варваров», тогда как Клавдиан именовал Трибигильда «гетским начальником ал дерзновенным» (Claud. In Eutrop. II. 176-177). Тем не менее тот же Клавдиан сообщал, что «легионом римским гревтунги (Gruthungi) были, коих покорили мы, коим дали законы, коим дали поля и дома» (Claud. In Eutrop. II. 576-577).

Как отметил Х. Вольфрам, они продемонстрировали свою эффективность в противостоянии с гуннами, славившимися своими конными лучниками. Это означает, что гревтунги находились в кавалерийских частях [Вольфрам, 2003, с. 214, прим. 214]. В Notitia dignitatum не указаны какие-либо подразделения, дислоцировавшиеся в диоцезе Азия, который управлялся проконсулом с гражданскими и военными полномочиями $\left(\mathrm{ND}\right.$. Or. XX) ${ }^{21}$. Удаленность этой административно-территориальной единицы от границ империи позволяла обходиться без размещения постоянных сил на ее территории. Варвары же, вероятно, первоначально занимались исключительно сельскохозяйственными работами и были в срочном порядке призваны в армию из-за угрозы гуннского вторжения.

Не вызывает сомнений, что гревтунги перед отправлением в Эдессу располагались на Востоке. Во Фракии их отряды находиться не могли. Передислокация сил с Европейского континента могла занять значительное время, тогда как неприятельская угроза требовала оперативного реагирования. По всей вероятности, отряды гревтунгов были переброшены в Осроену сразу после получения известий о вторжении хионитов в Закавказье. Кроме того, имевшиеся в распоряжении императора Аркадия резервы были весьма невелики. Наиболее боеспособные части Восточной империи в составе армии, возглавляемой его отцом Феодосием I, в 394 г. были отправлены в Италию против узурпатора Евгения и вернулись в Константинополь только в конце 395 г. (Zos. V. 7. 4-5). Передислокация на Восток отрядов, подчинявшихся военному магистру Фракии, также маловероятна, поскольку это могло ослабить систему обороны империи у нижнего течения Дуная.

В 399 г. гревтунги подняли мятеж, который возглавил Трибигильд. Придворный поэт западноримского императора Гонория Клавдиан писал, что причиной бунта был отказ препозита священной опочивальни Евтропия вознаградить германца (Claud. In Eutrop. II. 174-180). Конечно, принимая во внимание вражду между Стилихоном, регентом при Гонории, и Евтропием, к этим сведениям необходимо отнестись с осторожностью. Зосим

${ }^{21}$ К. Цукерман датировал восточный список Notitia dignitatum 401 г. [Zuckerman, 1998, p. 146-147]. М. Куликовски считает, что данная часть документа создана между 392 и 394 гг. [Kulikowski, 2000, p. 360]. А.-М. Кайзер недавно выдвинула версию о его составлении в 398-405 гг. [Kaiser, 2015, p. 245]. 
упомянул, что Трибигильд перед восстанием посетил Константинополь, где, вероятно, был принят Евтропием. Добиться желаемого во время этой аудиенции германец не сумел и, вернувшись во Фригию, со своими подчиненными начал разорять азиатские провинции империи, опустошив также Лидию, Памфилию и Писидию (Zos. V. 13. 3-4).

Против мятежников были отправлены войска во главе с презентальным магистром (magister militum in praesenti) Гайной, готом по происхождению. Созомен писал, что он состоял в родстве с Трибигильдом, вследствие чего варвары объединили свои силы для совместного наступления на Константинополь (Soz. VIII. 4. 2). Однако в действительности Гайна являлся выходцем из другой готской общности - тервингов-вестготов, он не мог быть сородичем Трибигильда [Jones, Martindale, Morris, 1971, p. 379-380]. О «варварском заговоре» писал и Зосим, который неприязненно относился к германским переселенцам. По его словам, Гайна даже не предпринимал попыток дать бой гревтунгам, а позднее и вовсе примкнул к мятежникам (Zos. V. 14-17) [см. также: Козлов, 1977, с. 52-57] ${ }^{22}$. Как сообщал Филосторгий, гревтунги понесли тяжелые потери в боях с исаврами (Philost. XI. 8). По всей видимости, германцы встретили отпор со стороны легионов II и III Isaura, возглавляемых дуксом Исаврии (ND. Or. XXIX. 7-8). Таким образом, при дальнейшем продвижении на восток варвары были атакованы в горных перевалах Тавра и отступили в Писидию.

Возможно, именно после этой неудачи Трибигильд начал переговоры с Гайной, который наступал на мятежников с запада, а затем поддержал восстание презентального магистра против Евтропия ${ }^{23}$. Впоследствии отряды гревтунгов захватили Лампсак (совр. Лапсеки) и через Геллеспонт (совр. Дарданеллы, Чанаккале) переправились во Фракию, где Трибигильд был убит. Гайна же, установив контроль над Вифинией, сумел добиться отставки Евтропия и других неугодных ему приближенных Аркадия. Однако позднее сторонники военачальника в Константинополе были перебиты самими горожанами. Во время погрома погибло несколько тысяч готов, проживавших в византийской столице. Гревтунги же были разбиты военным магистром Востока Фравиттой при попытке переправиться с Херсонеса Фракийского (совр. Галлиполи, Гелиболу) обратно в Азию (Philost. XI. 8; Eunap. fr. 75-76, ed. C. Müller; Zos. V. 18-21).

$\mathrm{X}$. Вольфрам, анализируя причины бунта Трибигильда, полагал, что германец стремился к захвату власти в Восточной Римской империи [Вольфрам, 2003, с. 214]. Г. Альберт, в свою очередь, утверждал, что гревтунги, которые были обычными колонами, добивались повышения своего статуса. Они желали обладать такими же правами, как и тервинги-вестготы под предводительством Алариха ${ }^{24}$. Что касается Трибигильда, этот военачальник стремился получить назначение на более значимую военную должность [Albert, 1984, S. 92-98]. Такую точку зрения поддержал и В. Либешютц [Liebeschuetz, 1990, p. 100-101].

Впрочем, вероятно, что Евтропий действительно не выдал германцам дары, причитавшиеся за победу над хионитами. Такое решение могло оказать негативное влияние на авторитет Трибигильда в глазах его сородичей. Безусловно, эти варвары находились в восточноримской армии на регулярной основе, получая жалование от самого государства. Тем не менее Трибигильд воспринимался гревтунгами не просто как командир, назначенный на этот пост императором или его представителями. В варварских объединениях пе-

${ }^{22}$ Сходная позиция по отношению к варварам на службе Аркадия была высказана Синесием Киренским в трактатах «О царстве» и «О провидении». Как считал Е.П. Глушанин, суждения этого позднеантичного автора были вовсе не реакцией на преобладание германцев в военных структурах, но выражением поддержки сословия куриалов [Глушанин, 1987, с. 20-21; Gluschanin, 1989, S. 244-245].

${ }^{23}$ Причины мятежа Гайны заслуживают отдельного рассмотрения. Первоначально он действовал в интересах префекта претория Востока Кесария, противостоявшего Евтропию. Однако позднее восточноримский военачальник готского происхождения решил действовать против могущественного препозита священной опочивальни самостоятельно [Глушанин, 1987, с. 23; Gluschanin, 1989, S. 248; Heather, 1991, p. 207; Cameron, Long, 1993, p. 201-228].

${ }^{24}$ См. также работы Х. Вольфрама и П. Хизера, в которых изучалось положение вестготов Алариха в Восточной Римской империи в 395-401 гг. [Вольфрам, 2003, с. 204-212; Heather, 1991, p. 204-208]. 
риода Великого переселения народов военные лидеры должны были обеспечить распределение добычи среди подчинявшихся им соратников, чтобы добиться их верности [Berndt, 2017, p. 21. Cp.: Dick, 2008, S. 196-202].

Трибигильд же не сумел убедить Евтропия выплатить достойное вознаграждение себе и своим подчиненным, вследствие чего предстал перед гревтунгами в невыгодном свете. Учитывая ранее проанализированные представления древних германцев о насилии, мятеж против императора, как и грабежи мирных жителей, были в представлении гревтунгов вполне приемлемым способом решения возникшей проблемы. При этом для варваров своеобразной «компенсацией» за неполученные донативы стало имущество горожан и крестьян Фригии, Лидии, Памфилии, Писидии.

Восстание позволило Трибигильду сохранить право оставаться лидером гревтунгов. По всей видимости, он не был выходцем из среды римской служилой знати и получил назначение на командный пост только при формировании подразделений из обитавших во Фригии дедитициев. Восточноримские власти видели в нем лицо, которое должно было осуществлять функции посредника между ними и рядовыми бойцами. Однако Трибигильд ориентировался не на демонстрацию лояльности императору как гарантию будущего карьерного роста, но на поиск поддержки среди других варваров, с которыми он был связан узами родства или боевого товарищества.

По сути, Трибигильд был «полевым командиром», то есть являлся политическим лидером, чья власть не имела правовых оснований и обеспечивалась лишь опорой на верные ему отряды. Варвар мыслил в рамках иной политической культуры, отличной от восточноримской. Протест его выражался не в стремлении заставить императора признать обоснованность своих притязаний, но в обособлении от центральной власти, попытке создать собственное потестарное образование. Впрочем, бунт гревтунгов был обречен на провал не только из-за малочисленности мятежников, но и ввиду отсутствия поддержки со стороны других сил, в особенности малоазийской провинциальной аристократии ${ }^{25}$.

При подведении итогов необходимо отметить, что Евтропий при отказе выдавать донативы отрядам гревтунгов не принял во внимание представления о воинской этике, распространенные среди обитателей barbaricum. Кроме того, фригийские гревтунги представляли собой достаточно крупное объединение чужеземцев, которые компактно проживали в диоцезе Азия. В случае недовольства решениями восточноримских властей они могли сплоченно выступить в защиту своих интересов. Поскольку подразделениями гревтунгов командовал их сородич, варвары имели возможность подготовиться к восстанию безо всякого противодействия со стороны военных, сохранявших верность императору Аркадию. Несомненно, неудачный опыт размещения варваров в империи был учтен восточноримскими властями, которые впоследствии стремились избегать подобных ошибок.

\section{Список литературы}

1. Вольфрам X. 2003. Готы: от истоков до середины VI века (опыт исторической этнографии). Пер. с нем. Б.П. Миловидова, М.Ю. Некрасова. СПб., Ювента, 656. (Wolfram H. 1979. Geschichte der Goten: Von den Anfängen bis zur Mitte des sechsten Jahrhunderts. Entwurf einer historischen Ethnographie. München, C.H. Beck, 506).

2. Гадло А.В. 1979. Этническая история Северного Кавказа IV-Х вв. Л., Наука, 216.

3. Ганина Н.А. 2001. Готская языческая лексика. М., Издательство МГУ, 176.

4. Глушанин Е.П. 1987. О некоторых причинах появления антиварварских настроений в общественно-политической мысли Византии конца IV - начала V в. Античная древность и средние века, 23: 14-25.

${ }^{25}$ Важно отметить, что неповиновение власти Равенны подобных «полевых командиров» (Эгидия в так называемом «Суассонском королевстве», Марцеллина в Далмации, короля вестготов Теодориха II на юго-западе Галлии и др.) в значительной мере содействовало распаду Западной Римской империи [MacGeorge, 2002; Wijnendaele, 2018, p. 432-443]. 
5. Козлов А.С. 1973. К вопросу о месте готов в социальной структуре Византии IV-V вв. Античная древность и средние века, 9: 114-121.

6. Козлов А.С. 1977. Некоторые аспекты «проблемы варваров» в «Новой истории» Зосима. Античная древность и средние века, 14: 52-59.

7. Мещерская Е.Н. 2006. Гурий, Самон(а) и Авив. В кн.: Православная энциклопедия. Т. 13. М., Православная энциклопедия: 485-487.

8. Пигулевская Н.В. 1940. Месопотамия на рубеже V-VI вв. Сирийская хроника Иешу Стилита как исторический источник. М., Издательство АН СССР, 176.

9. Пигулевская Н.В. 2017. Культура Сирии в Средние века. М., Ломоносовъ, 224.

10. Albert G. 1984. Goten in Konstantinopel: Untersuchungen zur oströmischen Geschichte um das Jahr 400 n. Chr. Paderborn, F. Schöningh, 211.

11. Berndt G.M. 2017. «The Goths Drew their Swords Together». Individual and Collective Acts of Violence by Gothic Warlords and their War Bands. In: Rogge J. (ed.). Killing and Being Killed: Bodies in Battle. Perspectives on Fighters in the Middle Ages. Bielefeld, transcript: 15-41.

12. Bidez J. (ed.). 1913. Philostorgius. Kirchengeschichte (mit dem Leben des Lucian von Antiochen und den Fragmenten eines arianischen Historiographen). Leipzig, J.C. Hinrichs, 508.

13. Bidez J. (ed.). 1995. Sozomenus. Kirchengeschichte. Berlin, Akademie Verlag, 617.

14. Bivar A.D.H. 2004. Hephtalites. In: Yarshater E. (ed.). Encyclopaedia Iranica. Vol. 12, Fasc. 2. London; Boston, Routledge \& Kegan Paul: 198-201.

15. Bright W. (ed.). 1893. Socrates' Ecclesiastical History. Oxford, Clarendon Press, 402.

16. Burkitt F.C. 1913. Euphemia and the Goth, with the Acts of Martyrdom of the Confessors of Edessa. London, Williams \& Norgate, 200.

17. Cameron Al., Long J. 1993. Barbarians and Politics at the Court of Arcadius. Berkeley; Los Angeles; Oxford, University of California Press, 480.

18. Chiesa P. 1991. Il dossier agiografico latino dei santi Gurias, Samonas e Abibos. Aevum, 65 (2): $221-258$.

19. Dewing H.B. (ed.). 1914. Procopius. History of the Wars. Vol. 1. London, W. Heinemann; Cambridge (Mass.), Harvard University Press, 600.

20. Dick S. 2008. Der Mythos vom «germanischen» Königtum: Studien zur Herrschaftsorganisation bei den germanischsprachigen Barbaren bis zum Beginn der Völkerwanderungszeit. Berlin; New York, De Gruyter, 270.

21. Dobschütz E. (ed.). 1911. Die Akten der edessenischen Bekenner Gurjas, Samonas und Abibos: Aus dem Nachlass von O. von Gebhardt. Leipzig, J.C. Hinrichs, 332.

22. Felix W. 1992. Chionites. In: Yarshater E. (ed.). Encyclopaedia Iranica. Vol. 5, Fasc. 5. London; Boston, Routledge \& Kegan Paul: 485-487.

23. Gluschanin E.P. 1989. Die Politik Theodosius' I. und die Hintergründe des sogenannten Antigermanismus im oströmischen Reich. Historia: Zeitschrift für Alte Geschichte, 38 (2): 224-249.

24. Golden P.B. 1992. An Introduction to the History of the Turkic Peoples: Ethnogenesis and State-formation in Medieval and Early Modern Eurasia and the Middle East. Wiesbaden, Harrassowitz, 497.

25. Heather P. 1991. Goths and Romans, 332-489. Oxford, Clarendon Press, 380.

26. Jones A.H.M. 1964. The Later Roman Empire, 284-602: A Social, Administrative and Economic Survey. Vol. 2. Oxford, B. Blackwell, 551.

27. Jones A.H.M., Martindale J.R., Morris J. (eds.). 1971. The Prosopography of the Later Roman Empire. Vol. 1. Cambridge, Cambridge University Press, 1170.

28. Kaiser A.M. 2015. Egyptian Units and the Reliability of the Notitia Dignitatum, Pars Oriens. Historia: Zeitschrift für Alte Geschichte, 64 (2): 243-261.

29. Kulikowski M. 2000. The «Notitia Dignitatum» as a Historical Source. Historia: Zeitschrift für Alte Geschichte, 49 (3): 358-377.

30. Lee A.D. 2007. War in Late Antiquity: A Social History. Malden; Oxford; Victoria, Blackwell Publishing, 312.

31. Liebeschuetz J.H.W.G. 1990. Barbarians and Bishops: Army, Church and State in the Age of Arcadius and Chrysostom. Oxford, Clarendon Press, 340.

32. MacGeorge P. 2002. Late Roman Warlords. Oxford, Oxford University Press, 364.

33. Martindale J.R. (ed.). 1980. The Prosopography of the Later Roman Empire. Vol. 2. Cambridge, Cambridge University Press, 1386. 
34. Müller C. (ed.). 1885. Eunapii Sardiani fragmenta. In: Fragmenta historicorum Graecorum. Vol. 4. Parisiis, A.F. Didot: 7-56.

35. Paschoud F. (ed.). 1979-1986. Zosime. Histoire nouvelle. T. 2-3. Paris, Les Belles Lettres.

36. Platnauer M. (ed.). 1922. Claudian. Vol. 1. Cambridge (Mass.): Harvard University Press, 432.

37. Seeck O. (ed.). 1876. Notitia dignitatum accedunt notitia urbis Constantinopolitanae et laterculi prouinciarum. Berolini, Weidmann, 339.

38. Seeck O. 1913. Geschichte des Untergangs der antiken Welt. Bd. 5. Stuttgart, J.B. Metzler, 424.

39. Wijnendaele J.W.P. 2018. Generalissimos and Warlords in the Late Roman West. In: Naco del Hoyo T., López Sánchez F. (eds.). War, Warlords, and Interstate Relations in the Ancient Mediterranean. Leiden; Boston, Brill: 427-451.

40. Zuckerman C. 1998. Comtes et dues en Égypte autour de l'an 400 et la date de la Notitia Dignitatum Orientis. Antiquité Tardive, 6: 137-147.

\section{References}

1. Wolfram H. 2003. Goty: ot istokov do serediny VI veka (opyt istoricheskoj etnografii) [The Goths: From the Origins to the Middle of the 6th Century (the Experience of Historical Ethnography)]. Transl. from German by B.P. Milovidov, M.Ju. Nekrasov. Saint Petersburg, Juventa, 656 (Wolfram H. 1979. Geschichte der Goten: Von den Anfängen bis zur Mitte des sechsten Jahrhunderts. Entwurf einer historischen Ethnographie. München, C.H. Beck, 506) (in Russian).

2. Gadlo A.V. 1979. Etnicheskaja istorija Severnogo Kavkaza IV-H vv. [Ethnic History of the North Caucasus]. Leningrad, Nauka, 216 (in Russian).

3. Ganina N.A. 2001. Gotskaja jazycheskaja leksika [Gothic Pagan Vocabulary]. Moscow, Moscow State University Press, 176 (in Russian).

4. Glushanin E.P. 1987. O nekotoryh prichinah pojavlenija antivarvarskih nastroenij v obshhestvenno-politicheskoj mysli Vizantii konca IV - nachala V v. [On Some Reasons of the Emergence of Antibarbarian Sentiments in the Sociopolitical Thought of Byzantium in the Later 4th to Early $5^{\text {th }}$ Century]. Antichnaja drevnost' i srednie veka [Antiquity and the Middle Ages], 23: 14-25 (in Russian).

5. Kozlov A.S. 1973. K voprosu o meste gotov v social'noj strukture Vizantii IV-V vv. [To the Question about the Place of Goths in the Social Structure of Byzantium in the 4th and 5th Centuries]. Antichnaja drevnost' i srednie veka [Antiquity and the Middle Ages], 9: 114-121 (in Russian).

6. Kozlov A.S. 1977. Nekotorye aspekty «problemy varvarov» V «Novoj istorii» Zosima [Some Aspects of the «Problem of Barbarians» in the «New History» by Zosimus]. Antichnaja drevnost' i srednie veka [Antiquity and the Middle Ages], 14: 52-59 (in Russian).

7. Meshcherskaja E.N. 2006. Gurij, Samon(a) i Aviv [Gurias, Samona, and Abibus]. In: Pravoslavnaja jenciklopedija [The Orthodox Encyclopedia]. T. 13. Moscow, Pravoslavnaja enciklopedija: 485-487 (in Russian).

8. Pigulevskaja N.V. 1940. Mesopotamija na rubezhe V-VI vv. Sirijskaja hronika Ieshu Stilita kak istoricheskij istochnik [Mesopotamia at the Turn of the $5^{\text {th }}$ into $6^{\text {th }}$ Century. The Chronicle by Joshua the Stylite as a Historian Source]. Moscow, Academy of Sciences of USSR Publishing, 176 (in Russian).

9. Pigulevskaja N.V. 2017. Kul'tura Sirii v Srednie veka [Culture of Syria in the Middle Ages]. Moscow, Lomonosov, 224 (in Russian).

10. Albert G. 1984. Goten in Konstantinopel: Untersuchungen zur oströmischen Geschichte um das Jahr 400 n. Chr. Paderborn, F. Schöningh, 211.

11. Berndt G.M. 2017. «The Goths Drew their Swords Together». Individual and Collective Acts of Violence by Gothic Warlords and their War Bands. In: Rogge J. (ed.). Killing and Being Killed: Bodies in Battle. Perspectives on Fighters in the Middle Ages. Bielefeld, transcript: 15-41.

12. Bidez J. (ed.). 1913. Philostorgius. Kirchengeschichte (mit dem Leben des Lucian von Antiochen und den Fragmenten eines arianischen Historiographen). Leipzig, J.C. Hinrichs, 508.

13. Bidez J. (ed.). 1995. Sozomenus. Kirchengeschichte. Berlin, Akademie Verlag, 617.

14. Bivar A.D.H. 2004. Hephtalites. In: Yarshater E. (ed.). Encyclopaedia Iranica. Vol. 12, Fasc. 2. London; Boston, Routledge \& Kegan Paul: 198-201.

15. Bright W. (ed.). 1893. Socrates' Ecclesiastical History. Oxford, Clarendon Press, 402.

16. Burkitt F.C. 1913. Euphemia and the Goth, with the Acts of Martyrdom of the Confessors of Edessa. London, Williams \& Norgate, 200. 
17. Cameron Al., Long J. 1993. Barbarians and Politics at the Court of Arcadius. Berkeley; Los Angeles; Oxford, University of California Press, 480.

18. Chiesa P. 1991. Il dossier agiografico latino dei santi Gurias, Samonas e Abibos. Aevum, 65 (2): $221-258$.

19. Dewing H.B. (ed.). 1914. Procopius. History of the Wars. Vol. 1. London, W. Heinemann; Cambridge (Mass.), Harvard University Press, 600.

20. Dick S. 2008. Der Mythos vom «germanischen» Königtum: Studien zur Herrschaftsorganisation bei den germanischsprachigen Barbaren bis zum Beginn der Völkerwanderungszeit. Berlin; New York, De Gruyter, 270.

21. Dobschütz E. (ed.). 1911. Die Akten der edessenischen Bekenner Gurjas, Samonas und Abibos: Aus dem Nachlass von O. von Gebhardt. Leipzig, J.C. Hinrichs, 332.

22. Felix W. 1992. Chionites. In: Yarshater E. (ed.). Encyclopaedia Iranica. Vol. 5, Fasc. 5. London; Boston, Routledge \& Kegan Paul: 485-487.

23. Gluschanin E.P. 1989. Die Politik Theodosius' I. und die Hintergründe des sogenannten Antigermanismus im oströmischen Reich. Historia: Zeitschrift für Alte Geschichte, 38 (2): 224-249.

24. Golden P.B. 1992. An Introduction to the History of the Turkic Peoples: Ethnogenesis and State-formation in Medieval and Early Modern Eurasia and the Middle East. Wiesbaden, Harrassowitz, 497.

25. Heather P. 1991. Goths and Romans, 332-489. Oxford, Clarendon Press, 380.

26. Jones A.H.M. 1964. The Later Roman Empire, 284-602: A Social, Administrative and Economic Survey. Vol. 2. Oxford, B. Blackwell, 551.

27. Jones A.H.M., Martindale J.R., Morris J. (eds.). 1971. The Prosopography of the Later Roman Empire. Vol. 1. Cambridge, Cambridge University Press, 1170.

28. Kaiser A.M. 2015. Egyptian Units and the Reliability of the Notitia Dignitatum, Pars Oriens. Historia: Zeitschrift für Alte Geschichte, 64 (2): 243-261.

29. Kulikowski M. 2000. The «Notitia Dignitatum» as a Historical Source. Historia: Zeitschrift für Alte Geschichte, 49 (3): 358-377.

30. Lee A.D. 2007. War in Late Antiquity: A Social History. Malden; Oxford; Victoria, Blackwell Publishing, 312.

31. Liebeschuetz J.H.W.G. 1990. Barbarians and Bishops: Army, Church and State in the Age of Arcadius and Chrysostom. Oxford, Clarendon Press, 340.

32. MacGeorge P. 2002. Late Roman Warlords. Oxford, Oxford University Press, 364.

33. Martindale J.R. (ed.). 1980. The Prosopography of the Later Roman Empire. Vol. 2. Cambridge, Cambridge University Press, 1386.

34. Müller C. (ed.). 1885. Eunapii Sardiani fragmenta. In: Fragmenta historicorum Graecorum. Vol. 4. Parisiis, A.F. Didot: 7-56.

35. Paschoud F. (ed.). 1979-1986. Zosime. Histoire nouvelle. T. 2-3. Paris, Les Belles Lettres.

36. Platnauer M. (ed.). 1922. Claudian. Vol. 1. Cambridge (Mass.): Harvard University Press, 432.

37. Seeck O. (ed.). 1876. Notitia dignitatum accedunt notitia urbis Constantinopolitanae et laterculi prouinciarum. Berolini, Weidmann, 339.

38. Seeck O. 1913. Geschichte des Untergangs der antiken Welt. Bd. 5. Stuttgart, J.B. Metzler, 424.

39. Wijnendaele J.W.P. 2018. Generalissimos and Warlords in the Late Roman West. In: Naco del Hoyo T., López Sánchez F. (eds.). War, Warlords, and Interstate Relations in the Ancient Mediterranean. Leiden; Boston, Brill: 427-451.

40. Zuckerman C. 1998. Comtes et dues en Égypte autour de l'an 400 et la date de la Notitia Dignitatum Orientis. Antiquité Tardive, 6: 137-147.

\section{ИНФОРМАЦИЯ ОБ АВТОРЕ}

Назаров Андрей Дмитриевич, инженерисследователь Уральского гуманитарного института Уральского федерального университета им. первого Президента России Б.Н. Ельцина, г. Екатеринбург, Россия

\section{INFORMATION ABOUT THE AUTHOR}

Andrey D. Nazarov, Research Engineer, Ural Humanitarian Institute, Ural Federal University the first President of Russia B.N. Yeltsin, Yekaterinburg, Russia 